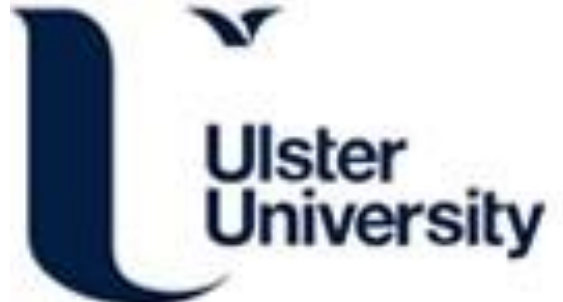

\section{They cannot sit properly or move around: seating and mobility during treatment for developmental dysplasia of the hip in children}

Cox, SL., \& Kernohan, W. G. (Accepted/In press). They cannot sit properly or move around: seating and mobility during treatment for developmental dysplasia of the hip in children. Pediatric Rehabilitation, 2(3), $129-134$. http://www.tandfonline.com/doi/pdf/10.3109/17518429809057424

Link to publication record in Ulster University Research Portal

Published in:

Pediatric Rehabilitation

Publication Status:

Accepted/In press: 01/06/1998

\section{Document Version}

Publisher's PDF, also known as Version of record

\section{General rights}

Copyright for the publications made accessible via Ulster University's Research Portal is retained by the author(s) and / or other copyright owners and it is a condition of accessing these publications that users recognise and abide by the legal requirements associated with these rights.

\section{Take down policy}

The Research Portal is Ulster University's institutional repository that provides access to Ulster's research outputs. Every effort has been made to ensure that content in the Research Portal does not infringe any person's rights, or applicable UK laws. If you discover content in the Research Portal that you believe breaches copyright or violates any law, please contact pure-support@ulster.ac.uk. 


\section{Pediatric Rehabilitation}

\section{They cannot sit properly or move around: seating and mobility during treatment for developmental dysplasia of the hip in children}

\section{Sara L. Cox \& W. George Kernohan}

To cite this article: Sara L. Cox \& W. George Kernohan (1998) They cannot sit properly or move around: seating and mobility during treatment for developmental dysplasia of the hip in children, Pediatric Rehabilitation, 2:3, 129-134, DOI: 10.3109/17518429809057424

To link to this article: https://doi.org/10.3109/17518429809057424

Published online: 10 Jul 2009.

Submit your article to this journal $\llbracket$

凹ll Article views: 21

View related articles $\nearrow$ 


\title{
They cannot sit properly or move around: seating and mobility during treatment for developmental dysplasia of the hip in children
}

\author{
SARA L. COX and W. GEORGE KERNOHAN
}

Accepted for publication: June 1998

Keywords seating mobility, splint, hip-dysplasia

\section{Summary}

Children diagnosed with Developmental Dysplasia of the Hip ( $0.2 \%$ of live births) are often treated by splintage to hold the head of the femur in the acetabulum during early joint development. Whilst clinically effective, this can create difficulties for the parents in handling the child and affects the mobility of the family, which subsequently creates emotional and social difficulty resulting from the disruption of the family routine. To identify these problems and their order of priority, a survey of 113 recently affected families was carried out in England and Northern Ireland. Parents identified mobility, emotional and social problems. Splintage size and shape was the fundamental problem from which the other difficulties arose. Solutions to the basic difficulties of transporting and seating a child in splintage would largely alleviate the feelings of frustration felt by the families and enable more normal activities of daily living.

\section{Introduction}

Developmental Dysplasia of the Hip (DDH) is a condition affecting two per 1000 live births [1]. It is a condition that mainly develops during and after the neonatal period and is characterized by a structural mal-position of the hip, that is defined as dislocated, dislocatable or subluxed [2]. In the early stages, it is a treatable disorder, i.e. it is possible to prevent later permanent disability. DDH is more common in female children [3, 4]. Children who experience late diagnosis of

Authors: Sara Cox (author for correspondence), Department of Mechanical and Aeronautical Engineering, University of Limerick, Ireland; George Kernohan, School of Health Sciences, University of Ulster, Newtonabbey, BT37 0QB, N. Ireland, UK.
DDH, after 3 months of age [1], pose a greater handling difficulty for their parents than those treated during the neonatal period. This is due to their greater physical size and the nature of the treatment required to correct the dysplasia. Such cases may be treated by orthopedic surgery and then splintage. The form taken by the splintage is dependent on the surgeon's assessment of the treatment needed but usually consists of plaster of Paris bandages followed by mechanical splinting devices [5-7].

Plaster of Paris splints are variations of two basic shapes: double hip spica and one-and-a-half hip spica. The former is applied after the child has undergone a closed reduction operation. The plaster is applied from nipple line to ankles on both sides and the legs are held in an abducted position with the knees flexed as illustrated in figure 1. Angles of abduction do not appear in the literature but the authors' pilot work of 13 children in plaster splintage indicated a total angle between the inside of one thigh and the inside of the other from form $64-180^{\circ}$. It was difficult to measure the individual angle of abduction on each leg as it was not possible to accurately locate the median plane. Careful approximation suggested an individual abduction angle of between 35 and $95^{\circ}$. This type of plaster splint is routinely applied for periods of up to 9 months [8].

The one-and-a-half hip spica splint is applied after open reduction for surgical procedures. The plaster bandage is applied from nipple line down to the ankle on the affected side and to the knee on the other side as shown in figure 2. In cases of bilateral dysplasia the plaster bandage would extend to the ankle on both sides. These splints are usually applied for a post operative period of 6 weeks.

Both types of plaster splints may be fitted with an abduction bar from ankle to ankle to strengthen the plaster and prevent movement of the hip. Mechanical splinting devices are usually applied after a period of treatment in plaster. They are used where there is a need for support but not for complete immobility and 


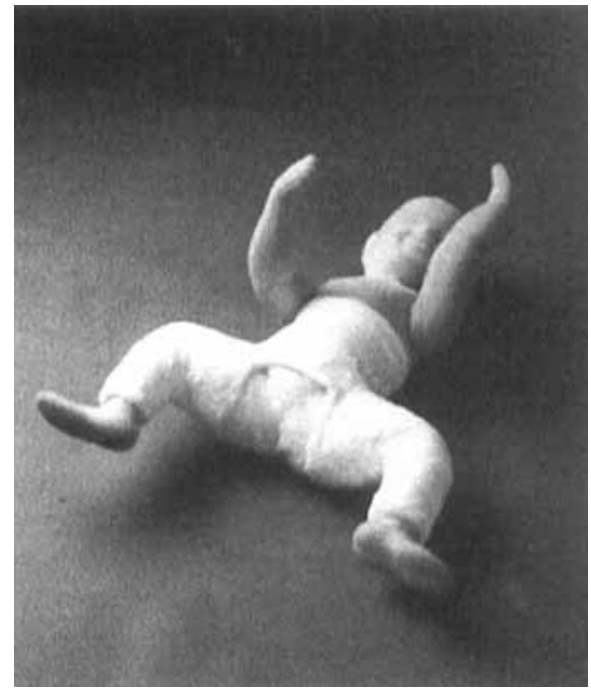

Figure 1 A clothing dummy representing an 18 month old child plastered in a double hip spica plaster splint or 'Lorenz' plaster. (Photograph by Eoin Stephenson).

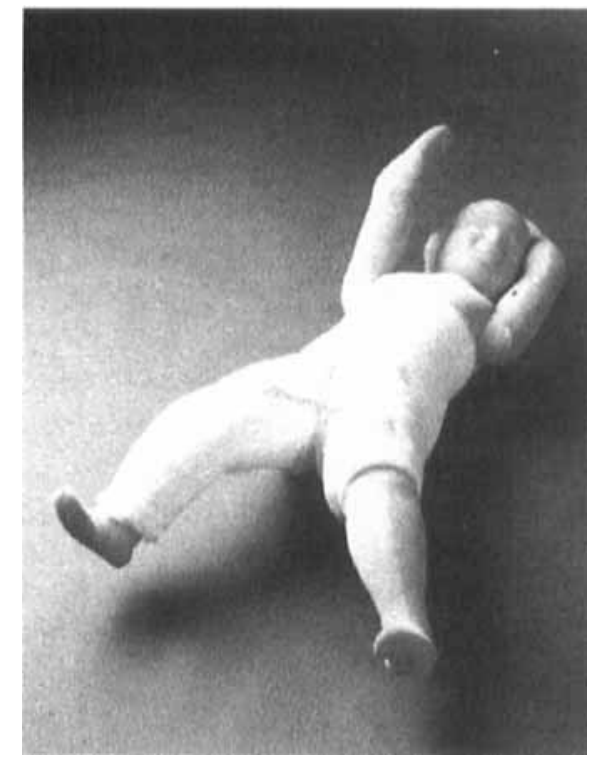

Figure 2 A one-and-a-half hip spica plaster splint with an abduction bar, on a clothing dummy representing a 2-year-old child. (Photograph by Eoin Stephenson).

allow the child some flexibility of movement while still retaining the abducted position that will enable the hip to continue developmental growth. The Denis Browne Harness is the main mechanical splinting device used in Great Britain [5].

From a handling point of view, treatment by splintage results in an unwieldy child in a heavy plaster of Paris cast with the legs at an awkward angle. The abduction angle needed to correct the dysplasia can preclude the use of normal accessories and mobility devices. The extent to which this can cause disruption to the normal activities of daily living of the family resulting in emotional, social and physical problems for both the parents and child, is the subject of this report.

\section{Method}

A questionnaire was developed based on the activities of daily living that were established for families with children between 3 months and 3 years old. A typical series of activities is demonstrated in figure 3. These activities were derived from the functional-life-scale that was developed to assess the ability of patients, who had suffered a cardiovascular accident, to complete the activities of daily living [9]. This information enabled the instrument to be designed in detail, to obtain information that would identify the problems and requirements of families with a child in splintage. The questionnaire consisted of seven sections, two of which were further sub-divided [10]. In total, there were 89 questions, 35 of which were structured and 54 open questions that required descriptive answers [11]. It was evaluated using a pilot study before distribution [12]. The data collected from the questionnaires was sorted into 'known facts', those that were qualitative, and 'variables', those that had descriptive and subjective answers. These were then analysed and the problems identified.

\section{Results}

A total of 113 questionnaires were distributed, of which, 10 were distributed in England and three were obtained through interview with parents in the children's ward at Musgrave Park Hospital, Belfast. The remaining 100 questionnaires were distributed to the parents of children who were undergoing or had undergone treatment at the hospital. Thirty eight questionnaires were returned giving a response rate of $34 \%$. The results of one questionnaire were dubious as it was not clear that the child had DDH and this was excluded from the study.

The data collected was analysed using the three 'P's framework: People, Places and Processes and the user characteristics of the sample population were identified [13]. This included the 'users', the 'environment' of use and the 'processes' involved. This information set the background to the problem analysis which was amassed from the postal survey. 


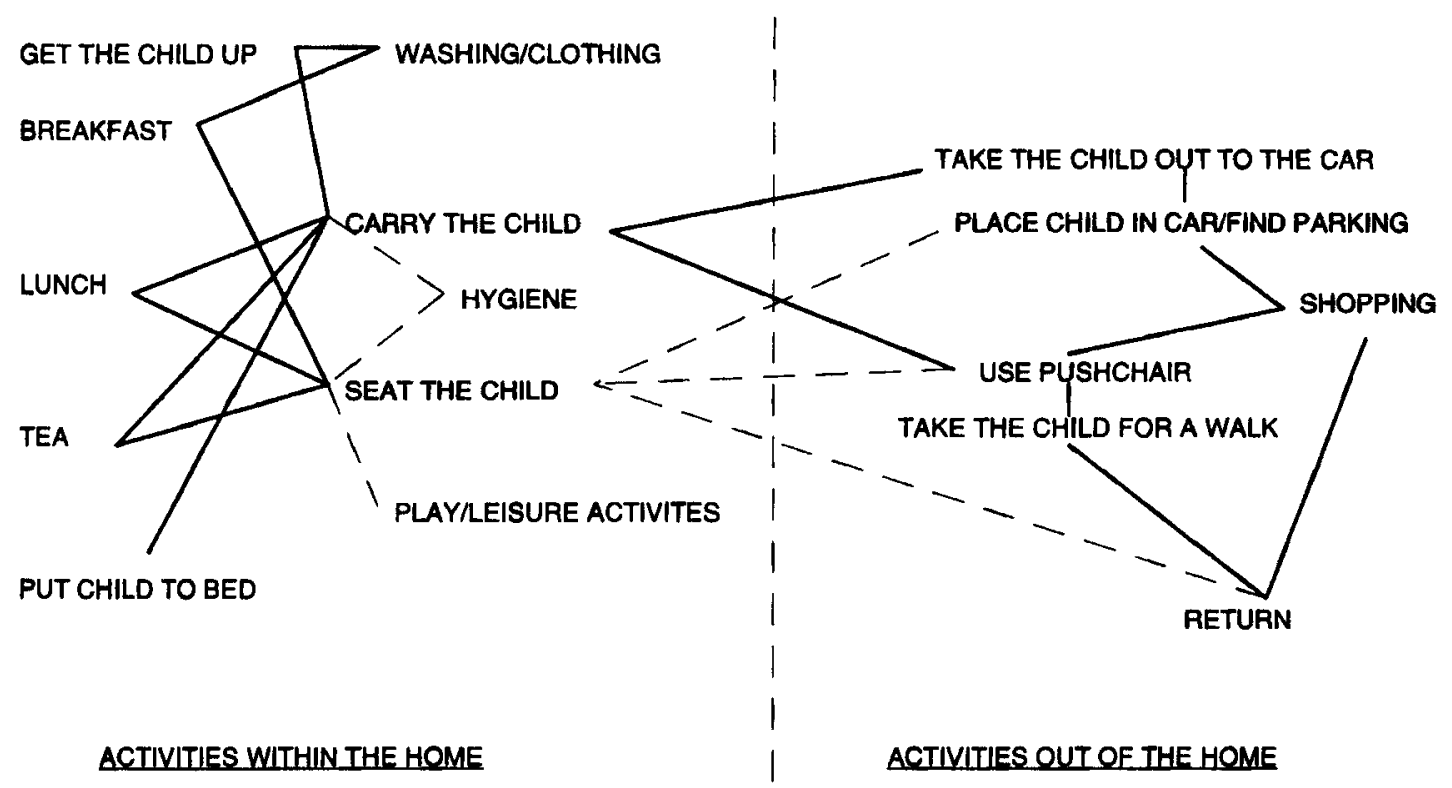

Figure 3 The typical activities of daily living that may take place during one day.

There were 61 problems identified by the parents as shown in table 1 . These were categorized as problems of mobility and seating and social and emotional problems, although, in some cases these were inter-dependent. Problems of mobility were identified 325 times or $9.6 \%$ of the total possible number of answers, emotional problems were identified 83 times $(2.5 \%)$ and social problems were mentioned 60 times $(1.8 \%)$. It was found that emotional problems consisted primarily of child and parental reactions to the diagnosis and treatment of the condition and in some cases to the lack of equipment and support when caring for the child at home. Social problems consisted of the difficulties of hygiene, lack of suitable clothing and the adverse reactions of others to the child's splintage. Mobility problems were found to consist of all aspects of carrying, transporting and seating the child and a lack of suitable equipment to facilitate this.

\section{Discussion}

The splintage used in the treatment of DDH was the fundamental problem from which the other problems of mobility and seating developed that affected the activities of daily living. This is demonstrated in figure 4 . It was found that, as a result of the child's loss of mobility, the parent (usually the mother) lifted and carried the child more frequently than would be necessary during normal child development. This became more difficult when the child was older as the size and weight, together with the awkward shape of the splintage, increased the risk of injury to the parent's back [14]. However, it was necessary to lift and carry the child for the purposes of moving between rooms including stairways, arranging seating, putting the child to bed, adjusting the child's position, using a pushchair and transporting the child by car. It was also necessary to lift the child for the purposes of hygiene and toileting.

The lack of seating in the home resulted in improvized support for the child, usually on the floor using a beanbag or cushion. The need for more frequent lifting of the child from floor level increased the physical strain on the parents. Lifting from floor level can increase the intervertebral disc pressure between the third and fourth lumbar vertebrae by up to $250 \%$ [15]. The position on the floor also had the effect of limiting the child's movements, which emphasized the loss of dignity that these children suffered through their loss of independence and sudden dependence on their parents at a time when they would normally be developing through exploration of their environment and learning from their actions.

Another common problem was the need to adapt equipment for mobility and seating. Adaptation occurred wherever there was an interface with existing equipment designed for 'normal' children. Each adaptation was unique and dependant on the shape of the splintage. Adaptation of products sometimes resulted in the loss of features with consequent loss of safety for the child. This occurred when using pushchairs into which the child could not be safety strapped, and 


\section{S. L. Cox and W. G. Kernohan}

Table 1 The summary of the problems identified in the postal survey, showing the number of times that each problem was cited, categorized as emotional problems, social problems or problems of mobility

\begin{tabular}{|c|c|c|c|}
\hline & Emotional & Social & Mobility \\
\hline $\begin{array}{l}\text { General } \\
\text { Child showed distress } \\
\text { Residual emotional problems (child) } \\
\text { Sibling/s over protective } \\
\text { Disturbance of routine for other child } \\
\text { Sibling distress } \\
\text { Parental distress and shock } \\
\text { Separation of family } \\
\text { Diagnosis of second child } \\
\text { Advice on DDH and care at home (parental support) } \\
\text { No clothing available for the child }\end{array}$ & $\begin{array}{r}5 \\
4 \\
3 \\
\\
1 \\
30 \\
\\
2 \\
8\end{array}$ & l & \\
\hline $\begin{array}{l}\text { Mobility } \\
\text { Coping with mobility } \\
\text { Lack of equipment for mobility } \\
\text { Getting through doorways-wide abduction } \\
\text { Adaptation to pushchair or pram } \\
\text { Lack of understanding by other children } \\
\text { Lack of understanding by other adults } \\
\text { Parental feeling of stigma }\end{array}$ & 6 & $\begin{array}{r}6 \\
10\end{array}$ & $\begin{array}{r}5 \\
34 \\
6 \\
27\end{array}$ \\
\hline $\begin{array}{l}\text { Lifting and carrying } \\
\text { Plaster weight } \\
\text { Plaster shape } \\
\text { Damage to plaster due to lifting } \\
\text { Back injury to mother due to lifting } \\
\text { Carrying the child upstairs } \\
\text { The size and weight of the splintage affecting the child's mobility }\end{array}$ & 3 & & $\begin{array}{l}31 \\
15 \\
1 \\
3 \\
8\end{array}$ \\
\hline $\begin{array}{l}\text { Using a car } \\
\text { Required two persons to place child in the car } \\
\text { Awkward to lift into/out of the car } \\
\text { Back injury to mother due to lifting } \\
\text { No safe restraint available } \\
\text { Adaptation to an existing child car seat } \\
\text { Child held by an adult } \\
\text { Adaptation using adult seat belts/seat } \\
\text { Using a specially designed car seat } \\
\text { The belts could not be used safely } \\
\text { Seat was in adequate } \\
\text { Not safe }\end{array}$ & & & $\begin{array}{r}6 \\
6 \\
1 \\
14 \\
12 \\
13 \\
5 \\
1 \\
3 \\
6 \\
6\end{array}$ \\
\hline $\begin{array}{l}\text { Holidays } \\
\text { The child would have been uncomfortable in the splintage } \\
\text { The parents found it too difficult } \\
\text { The parents had other commitments } \\
\text { Fear of accident or injury to the child } \\
\text { Using public transport } \\
\text { Difficulty coping with the child } \\
\text { Difficult to stow the chair safety }\end{array}$ & $\begin{array}{l}5 \\
2\end{array}$ & 3 & $\begin{array}{l}3 \\
1\end{array}$ \\
\hline $\begin{array}{l}\text { Eating } \\
\text { Adaptation of existing equipment/special chairs } \\
\text { No equipment-cushions, beanbags and pillows } \\
\text { Seated on the floor-cushions and pillows } \\
\text { Seated on parent's lap } \\
\text { Using a special table }\end{array}$ & & & $\begin{array}{r}19 \\
8 \\
7 \\
7 \\
1\end{array}$ \\
\hline $\begin{array}{l}\text { Sleeping } \\
\text { Adaptation to existing bed/cots } \\
\text { Special accommodation }\end{array}$ & & & $\begin{array}{r}16 \\
3\end{array}$ \\
\hline
\end{tabular}


Table 1 (continued)

\begin{tabular}{|c|c|c|c|}
\hline & Emotional & Social & Mobility \\
\hline \multicolumn{4}{|l|}{ Hygiene } \\
\hline Keeping the plaster clean, toileting & & 33 & \\
\hline Reverting back to nappies & & 2 & \\
\hline Two people required to wash the child's hair & & & 2 \\
\hline Adaptation to washing facilities to prevent the plaster from getting wet & & & 38 \\
\hline \multicolumn{4}{|l|}{ Play } \\
\hline \multicolumn{4}{|l|}{ Support required while playing games: } \\
\hline Floor-cushions and beanbags & & & 2 \\
\hline Adaptations of existing equipment & & & 4 \\
\hline Adult's lap & & & 4 \\
\hline Fear of damage to the plaster & 3 & & \\
\hline Fear of injury to the child & 6 & & \\
\hline Fear of injury to other children & 4 & & \\
\hline \multicolumn{4}{|l|}{ School } \\
\hline Unable to place the child on the floor & & & 1 \\
\hline Mother had to hold the child & & & 1 \\
\hline Loss of contact with friends & & 2 & \\
\hline
\end{tabular}

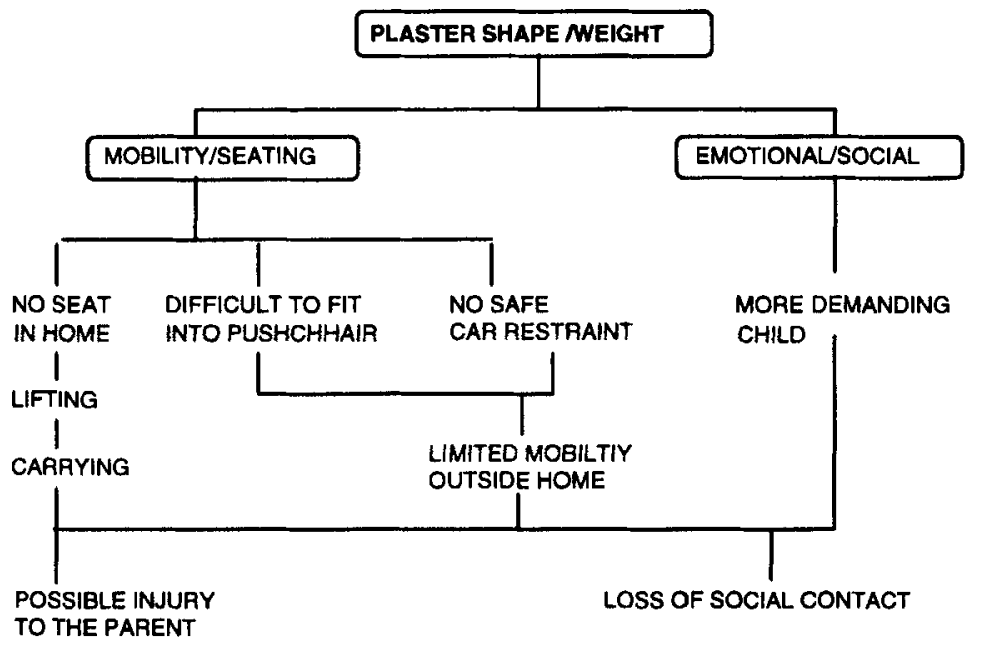

THE FUNDAMENTAL PROBLEM

Figure 4 A summary of the problems created by the abduction splintage during the activities of daily living.

in the misuse of child restraint systems in cars, with the consequent danger to the child during travel [16].

A direct result of the fundamental problem of the splintage was the increased dependence on the parent, by the child, for the performance of tasks, and for comfort and reassurance. The lack of suitable equipment sometimes made it impossible for the parents and child to accomplish their social and leisure activities. This resulted in a feeling of isolation for the parents and loss of social contact with other children by the child. Parents also found that this disrupted their child's social development.

The cost of buying additional items of equipment and adapting new items of clothing, was an additional financial stress to some parents who found that their own baby equipment was inappropriate. This placed an extra burden on the family's finances at a time when they were travelling to hospital more frequently, using more nappies, etc. However, some parents were prepared to buy items if these provided better facilities for their child during the treatment period.

The problem analysis demonstrated that the majority of problems created by the splintage were the result of the child's loss of mobility and the lack of available equipment to support the child in a seated position. This lack of 'mobility' and the problems of 'seating' the child, despite adaptations to existing equipment, restricted the child's movements and as a result also restricted the parent's activity. In some cases, this had economic and social implications as the parent had dif- 
ficulty continuing at work while the child was immobile and both suffered from a lack of social contact with others.

\section{Conclusion}

In treatment for DDH there are problems with mobility and seating. Analysis of user behaviour patterns demonstrated that, because of the child's abduction splintage, seating was an important element in the performance of the different aspects of mobility needed during the activities of daily living. The inability of the parents to seat the child not only increased the child's dependence on the parent but created potentially dangerous situations in the performance of some of these activities. This was especially apparent during transport of these children by car as there were no suitable safe child restraint systems available for use with splintage. These problems could be alleviated in this population by the provision of specialized devices that would allow mobility by car, in a pushchair and provide seating in the home.

\section{References}

1. Lennox, I. A. C., Mclauchlan, J. and Murali, R.: Failures of screening and management of congenital Dislocation of the Hip. Journal of Bone and Joint Surgery, 75-B: 72-75, 1993.

2. Curry, L. C. and Gibsov, L. Y.: Congenital hip dislocation. The importance of early detection and comprehensive treatment. Nurse Practitioner, 17: 49-55, 1992.
3. Place, M. J., Parkin, D. M. and Fitton, J. M.: Effectiveness of neonatal screening for congenital dislocation of the hip. Lancet, 2 : 249-250, 1978.

4. Mackenzie, I. G. and Wilson, J. G.: Problems encountered in the early diagnosis and management of congenital dislocation of the hip. Journal of Bone and Joint Surgery, 63-B: 38-42, 1981.

5. Wilkinson, J. A.: Your child's congenital dislocation of the hip. A guide for parents (Southampton: University of Southampton), 1983.

6. Aiello, D. H.: Congenital dislocation of the hip: diagnosis, treatment, nursing care. Journal of the Association of Operating Room Nurses, 49: 1566-1606, 1989.

7. Adams, J. C. and Hamblen, D. L.: Outline of Orthopaedics (Edinburgh: Churchill Livingstone), pp. 285-293, 1990.

8. Banton, S.: C.D.H. - A Booklet for Parents (Lymm, Cheshire: STEPS), 1982.

9. Sarno, J. D., Sarno, M. T. and Levita, E.: The functional life scale. Archives of Physical Medicine and Rehabilitation, 54: 214-220, 1973.

10. Fowler, F. J.: Survey Research Methods (Newbury Park, California: Sage Publications), p. 102, 1988.

11. Jolliffe, F. R.: Survey Design and Analysis (Chichester: Ellis Horwood), p. 24, 1986.

12. Cox, S. L. and Mollan, R. A. B.: Problems of seating and mobility in children undergoing treatment for Developmental Dysplasia of the Hip. Clinical Rehabilitation, 9: 190-197, 1995.

13. Cox, S. L.: The use of 'User Requirements Analysis' in the design of products. In: Y. Quéinnec and F. Daniellou (editors) Designing for everyone (London: Taylor Francis), pp. 1052-1054, 1991.

14. GREENWOOD, A.: Your child in an immobilising plaster (London: The National Association for the Welfare of Children in Hospital), 1984.

15. Grandjean, E.: Fitting the Task to the Man (London: Taylor and Francis), pp. 106-112, 1988

16. ANON: Can you explain? Road accidents. Death and serious injury on the roads have reached epidemic proportions. Advice, 83: 2210 . 1982. 